\title{
Mortality of crested wheatgrass and Russian wildrye during drought
}

\author{
M.R. HAFERKAMP, P.O. CURRIE, J.D. VOLESKY, AND B.W. KNAPP
}

Authors are range scientist and range scientist (retired) USDA-ARS, Fort Keogh Livestock and Range Research Laboratory, Miles City, Mont. 59301; research animal scientist USDA-ARS, Forage and Livestock Research Laboratory, P.O. Box 1199, El Reno, Okla. 73036; and statistician, USDA-ARS, Fort Keogh Livestock and Range Research Laboratory, Miles City, Mont. 59301.

\section{Abstract}

From September 1987 through September 1988, the Northern Great Plains near Miles City, Mont., received 31\% of the long-term average precipitation. We monitored the impact of the hot, dry conditions during the growing season on mortality of tillers and plants of 'Vinall' Russian wildrye (Psathrostachys juncea [Fisch.] Nevski) and 'Nordan' crested wheatgrass (Agropyron desertorum [Fisch.] Schult). Plants were collected in the field, watered, and placed in controlled environments. Ninety-two percent of the wildrye plants collected in July produced green shoots. Fifty-seven percent of the wheatgrass plants collected in July produced shoots. The maximum percentage of wildrye and wheatgrass plants producing green shoots in August was significantly $(\boldsymbol{p} \leq \mathbf{0 . 1 0})$ less than in July. Transects were used to sample density of dormant and live plants after September rains, and plants were incubated as before. When transect and incubation data were combined, only $41 \%$ of the wildrye and $16 \%$ of the wheatgrass plants were deemed viable in September.

Key Words: plant death, temperature, precipitation, drought, Agropyron desertorum, Psathrostachys juncea

Crested wheatgrass (Agropyron desertorum [Fisch.] Schult) and Russian wildrye (Psathrostachys juncea [Fisch.] Nevski) are an integral part of many livestock operations in the Northern Great Plains, by providing an important forage base for spring and fall grazing. Utilization of the species during spring allows producers to delay grazing cattle on native ranges, and utilization during fall can extend the grazing period.

Currie and White (1982) found crested wheatgrass and Russian wildrye were more drought resistant than many other species recommended for seeding in the Northern Great Plains. Water stress combined with defoliation can, however, reduce production and affect persistence. Mortality of crested wheatgrass and Russian wildrye plants due to drought has been reported in Colorado (Currie 1970), Montana (Currie and White 1982), and Canada (McLean and van Ryswyk 1973). In all these studies, mortality was assessed in seeded stands following the season, year, or sequence of years of severe water stress, but rate of mortality was not documented during these stress periods. The objective of this study was to determine if loss of regrowth potential or plant death was detectable in stands of crested wheatgrass and Russian wildrye during the severely hot, dry conditions of 1988.

\footnotetext{
The authors express appreciation to Kevin Peterson, Cheryl Murphy, and several summer aides for their assistance in conducting the experiment, and Mary Ellen French for assistance with graphics.

This paper is a contribution from the USDA, Agricultural Research Service and Montana Agricultural Experiment Station, Miles City, Montana.

Publication has been approved by the Director of the Montana Agr. Exp. Sta. Journal Ser. J-2630.

Manuscript accepted 28 October 1991.
}

Materials and Methods

\section{Study Area}

Death loss was monitored for plants collected on the Fort Keogh Livestock and Range Research Laboratory $\left(46^{\circ} 22^{\prime} 30^{\prime \prime} \mathrm{N}\right.$; $36^{\circ} 50^{\prime} 00^{\prime \prime} \mathrm{W}$ ). Soils were a mix of fine-loamy, mixed, (calcareous) frigid Ustic Torriorthents, coarse-loamy, mixed, Borollic Camborthids, and fine-loamy, mixed (calcareous), frigid Ustic Torrifluvents. The crested wheatgrass pasture $(40 \mathrm{ha})$ was seeded in 1978 at a rate of $7.3 \mathrm{~kg} /$ ha in rows $35-\mathrm{cm}$ apart. The Russian wildrye pasture (55 ha) was seeded at a rate of $7.3 \mathrm{~kg} / \mathrm{ha}$ in rows $52-\mathrm{cm}$ apart. Each pasture was located next to a calving facility, and was usually stocked with 150 animal units (AU) for approximately 45 days during spring. Pastures were stocked at a similar rate in 1988 , but because of a lack of precipitation during winter and spring, plant growth was severely depressed, and alfalfa hay was fed as the total ration.

During the period 1978 through 1988, the local region received an average of $303 \mathrm{~mm}$ annual precipitation and $186 \mathrm{~mm}$ from September through May. The annual precipitation was $90 \%$ of the long-term (since 1900) average and September through May precipitation was $92 \%$ of average. Annual precipitation was average or above in 1978, 1982, 1986, and 1987. September through May precipitation was above average in 1978, 1979, 1982, 1986, and 1987.

The local region received $46 \mathrm{~mm}$ of precipitation in August 1987, $43 \mathrm{~mm}$ from September 1987 through March 1988, and $71 \mathrm{~mm}$ precipitation during April through September 1988 (Fig. 1). The April through September period was the driest ever recorded during the last 90 years. Maximum daytime temperatures during the evaluation period were $>38^{\circ} \mathrm{C}$ on 23 days.

\section{Measurements}

Collections of dormant (or dead) plants was begun in 1988, after spring grazing was terminated. One hundred plants were selected at 20-step intervals from selected areas within the experimental pastures on each of 2 dates, 11 July and 23 August 1988. The plant located nearest the toe of the pacer's right foot was chosen at each stop without regard to plant size. Plants were carefully excavated, to limit exposure of roots. Each plant was then placed in a plastic pot (14.6-cm top diameter, $11.4-\mathrm{cm}$ bottom diameter, and $14 \mathrm{~cm}$ tall), transported to the laboratory, and soaked with distilled water. Soil collected from the pastures was then added to each pot to eliminate air pockets.

Twenty five plants of each species were randomly selected and placed in 1 of 4 environments for either 35 days beginning 12 July or 29 days beginning 24 August. Environments were an in situ outside control and controlled environments of $5 / 10,10 / 20$, or $15 / 25^{\circ} \mathrm{C}$, with a 12 -hour photoperiod.

Following fall rains in September, density of dormant and green plants was estimated in 100 and $16330 \times 30-\mathrm{cm}$ quadrats distrib- 
uted across the wheatgrass and wildrye pastures, respectively. Assuming fall rains were inadequate for growth initiation, we also collected an additional 100 dormant plants of each species for a 35-day incubation period in the 4 test environments.

Number of plants producing green shoots was recorded daily. Water was added as required to maintain soil water content near field capacity. At the end of the incubation period, plant basal areas were estimated by counting squares in a grid overlaying the crown. Green shoots were also counted, harvested at the soil surface, oven-dried for 24 hours at $105^{\circ} \mathrm{C}$, and weighed.

Plant responses to increasing heat and water stress were estimated by comparing maximum percent of plants producing green shoots, plant basal area, shoot number per plant, and shoot weight between July and August collections. Maximum percent of plants was used instead of the percent remaining green at the end of the incubation period, because some tillers died during later stages of incubation. Means were compared using the $t$-test for samples with unequal or equal variances (Schlotzhauer and Littell 1987). Differences were considered significant at $p \leq 0.10$. No attempt was made to compare species, since they were growing in different row spacings on separate although adjacent sites. Means are presented with standard errors

\section{Results}

\section{July Collection}

Plants collected in July began growth soon after watering. Wildrye shoots initiated growth rapidly, and $50 \%$ of the plants produced green shoots within 5 days. Ultimately, $92 \%$ of the wildrye plants produced green shoots whereas $57 \%$ of the wheatgrass plants produced green shoots (Table 1).

Table 1. Averages and standard errors for maximum percent plants producing green shoots, basal area, number of green shoots per plant, and shoot weight per plant, for Russian wildrye and crested wheatgrass plants collected in 1988 near Miles City, Montana. Values are based on the average of 4 blocks with each containing 25 potted plants. Measurements were made after 35 days in a controlled environment beginning 12 July and 29 days beginning 24 August.

\begin{tabular}{|c|c|c|}
\hline Date & Russian wildrye & Crested wheatgrass \\
\hline $\begin{array}{l}\text { July } \\
\text { August }\end{array}$ & $\begin{array}{c}- \text { Maximum } \% p \\
92(0) \mathrm{a}^{1} \\
33(4) \mathrm{b}\end{array}$ & $\begin{array}{l}\text { producing green shoots- - } \\
57(7) \mathrm{a} \\
22(5) \mathrm{b}\end{array}$ \\
\hline $\begin{array}{l}\text { July } \\
\text { August }\end{array}$ & $\begin{array}{l}39(6) \mathrm{a} \\
50(1) \mathrm{a}\end{array}$ & $\begin{array}{l}\text { area } \mathrm{cm}^{2} \\
34(2) \mathrm{a} \\
47(3) \mathrm{b}\end{array}$ \\
\hline $\begin{array}{l}\text { July } \\
\text { August }\end{array}$ & $\begin{array}{c}26(3) \mathrm{a} \\
17(3) \mathrm{b}\end{array}$ & $\begin{array}{c}\text { er per plant } \ldots \ldots \ldots \\
11(1) \mathrm{a} \\
16(5) \mathrm{a}\end{array}$ \\
\hline $\begin{array}{l}\text { July } \\
\text { August }\end{array}$ & $\begin{array}{c}715(100) \mathrm{a} \\
248(73) \mathrm{b}\end{array}$ & $\begin{array}{l}\text { (mg) per plant } \\
244(46) \mathrm{a} \\
220(97) \mathrm{a}\end{array}$ \\
\hline
\end{tabular}

IMeans within a variable for each species followed by same letters are not significantly different at $P<0.10$

During the 24 days preceding the July collection, air temperatures exceeded $32^{\circ} \mathrm{C}$ during $28 \%$ of the 576 hours. Temperatures exceeded $35^{\circ} \mathrm{C}$ and $38^{\circ} \mathrm{C}$ for $16 \%$ and $7 \%$ of the same period, respectively. Soil temperatures at the $76-\mathrm{mm}$ and $152-\mathrm{mm}$ depths consistently exceeded $32^{\circ} \mathrm{C}$ during this time period.

\section{August Collection}

During the 25 -day watering period, $33 \%$ of the wildrye plants and $22 \%$ of the wheatgrass plants produced green shoots (Table 1). The additional 43 days of dry, hot conditions occurring in July and August before the August collection were detrimental to both wild- rye and wheatgrass plants. Maximum daytime temperatures exceeded $38^{\circ} \mathrm{C}$ on 14 days, and ambient air temperature exceeded $32^{\circ} \mathrm{C}, 35^{\circ} \mathrm{C}$, and $38^{\circ} \mathrm{C}$ during $16 \%, 8 \%$, and $1 \%$ of the 1032 hour time period, respectively. Only $8.4 \mathrm{~mm}$ of precipitation was received during this period (Fig. 1).

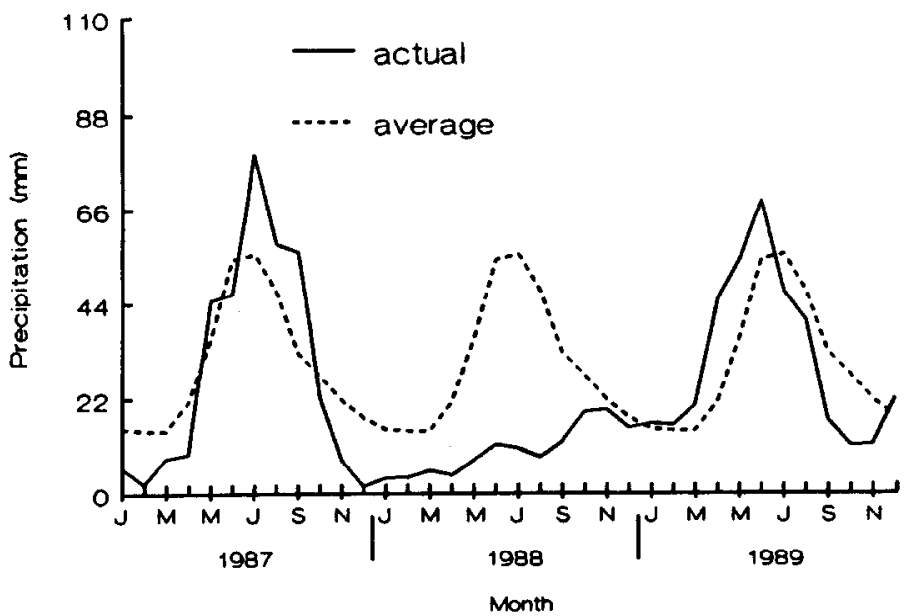

Fig. 1. Actual ( $ـ$ ) and long-term average (---) precipitation for Miles City, Mont., for 1987, 1988, and 1989 presented as a 3-month running average (NOAA 1987-1989).

The maximum number of plants producing green shoots in August was significantly less for both wildrye and wheatgrass than in July (Table 1). Average plant basal areas were similar for wildrye plants collected in July and August. Shoot density, shoot weight per plant, and weight per shoot were significantly greater, however, for wildrye plants collected in July than in August. These trends were not readily apparent for wheatgrass plants. Basal areas were significantly greater in August than July. However, shoot density, shoot weight per plant, and weight per shoot were similar for the 2 collections.

\section{September Collection}

Step transect results showed density of dormant wildrye and wheatgrass plants was greater than 10 plants $/ \mathrm{m}^{2}$ (Fig. 2). Density of

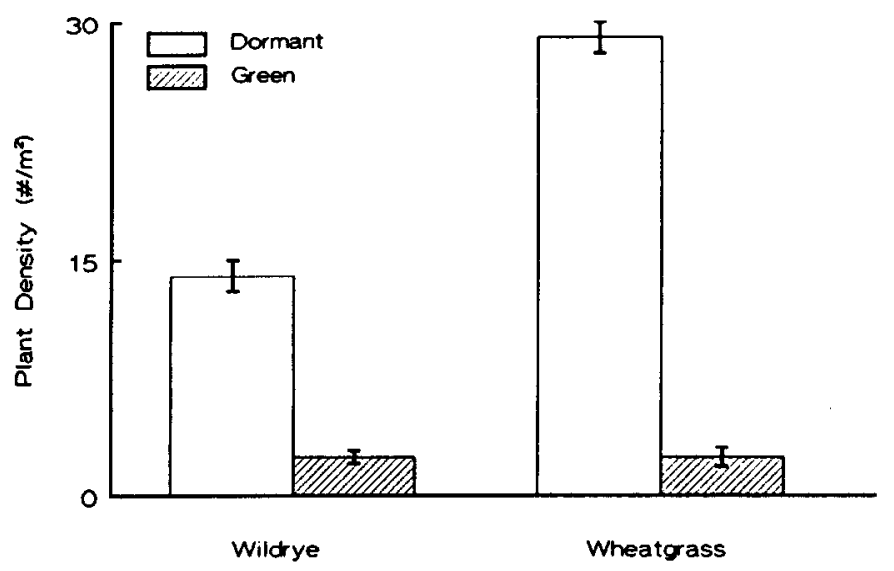

Fig. 2. Density $\left(\$ / \mathrm{m}^{2}\right)$ of dormant and green Russian wildrye and crested wheatgrass plants estimated by step transect on the experimental pastures in September 1988.

plants with green shoots, however, averaged only $2.4 \mathrm{plant} / \mathrm{m}^{2}$. When the dormant plants were collected and incubated in the laboratory, $21 \% \pm 3$ of the wildrye and $7 \%^{\circ} 2$ of the wheatgrass plants initiated growth. Combined transect and incubation data 
showed $41 \%$ of the wildrye plants and $16 \%$ of the wheatgrass plants were viable in September.

The study pastures received $25 \mathrm{~mm}$ of precipitation prior to the September collection (Fig. 1). Also during the 31-day interval before this collection, ambient air temperatures were less than during the summer, never exceeding $35^{\circ} \mathrm{C}$ and exceeding $32^{\circ} \mathrm{C}$ only $1 \%$ of the 744 -hour time interval.

\section{Discussion}

Dry, hot environmental conditions occurring during the 1988 growing season caused a significant die-off of both Russian wildrye and crested wheatgrass plants. Large areas of dead plants were still visible in spring 1989, but losses were not quantified because ranges were reseeded in the fall of 1988 and spring of 1989 . These results agree with those reported from Colorado, Canada, and Montana. Ground cover of crested wheatgrass was reduced by one third on spring grazed ranges and one half on fall and spring-fall grazed pastures in Colorado following a winter and spring of belowaverage precipitation in 1982 and 1983 (Currie 1970). Severe mortality, approaching $50 \%$, occurred on grazed and ungrazed Russian wildrye and crested wheatgrass stands following a severe dry period between spring 1970 and spring 1971 in Saskatchewan (Mclean and van Ryswyk 1973). Currie and White (1982) reported a significant reduction of 25 to $39 \%$ in basal area of crested wheatgrass plants in eastern Montana. Stands seeded in spring and fall 1978 were measured in 1981 following 3 years of below average precipitation.

Although loss of plant viability occurred continually for both species during the 1988 growing season, reductions in shoot number and weight were only noticeable for wildrye plants. McLean and van Ryswyk (1973) reported that mortality of crested wheatgrass in Saskatchewan probably began in early May when lack of soil moisture arrested phenological development and ceased in July when lowest soil water levels were attained. They suggested mortality was related to extreme drought during inflorescence development. Thus, significant, loss of shoot viability in our wheatgrass plants may have occurred before the first collection date. Reduction in shoot numbers was probably due to inactivation of axillary buds required for regrowth (Busso et al. 1989).
They reported this reduction in bluebunch wheatgrass (Pseudoroegneria spicata (Pursh) A. Love subsp. spicata) and crested wheatgrass was caused by extended periods of drought and defoliation. Defoliation in our study may have also been a factor affecting ultimate death of plants. Death of plants, however, continued to occur after all plants had been grazed during early spring.

The literature contains adequate evidence showing plants of crested wheatgrass and Russian wildrye die following periods of severe water stress, whether stress periods result from dry growing seasons or several years of drought. Results of this study clearly show these losses can occur continuously during a severely dry growing season. We assume these losses can be promoted by any factor that affects availability of soil water, such as, soil texture, soil structure, and presence of salts.

Reductions in potential for regrowth of seeded stands at Fort Keogh in 1988 severely impacted the forage base needed for spring and fall grazing. Land managers should be aware of the potential for losses in seeded stands as a result of a severely dry growing season when plants are growing on similar soils. This knowledge will provide additional flexibility and grazing management security to livestock operators encountering conditions similar to the severe dry, hot condition occurring in 1988 on the Northern Great Plains.

\section{Literature Cited}

Busso, C.A., R.J. Mueller, and J.H. Richards. 1989. Effect of drought and defoliation on bud viability in two caespitose grasses. Ann. Bot. 63:477-485

Currie, P.0. 1970. Influence of spring, fall, and spring-fall grazing on crested wheatgrass range. J. Range Manage. 23:103-108.

Currie, P.O., and R.S. White. 1982. Drought survival of selected forage grasses commonly seeded in the Northern Great Plains. Can. J. Plant Sci. 62:949-955.

McLean, A., and A.L. van Ryswyk. 1973. Mortality in crested wheatgrass and Russian wildrye. J. Range Manage. 26:431-433.

National Oceanic and Atmospheric Administration. 1987-1989. Climatological data annual summary, Montana. 90-92:13.

Schlotzhauer, S.D., and R.C. Littell. 1987. SAS system for elementary statistical analysis. SAS Institute Inc., Cary, N.C. 